\title{
Photoprotective Effects of Caffeic Acid against Ultraviolet- induced Damages on Human Follicle Dermal Papilla Cells
}

Kyu Joong Ahn

Department of Dermatology, Konkuk University School of Medicine, Seoul, Korea

Corresponding author: Kyu Joong Ahn, Department of Dermatology, Konkuk University School of Medicine, 120 Neungdong-ro, Gwangjin-gu, Seoul 05029, Korea

Tel.: +82 220305181

Fax: +82 230305179

Email: kjahn@kuh.ac.kr

Received January 31, 2017

Revised February 6, 2017

Accepted February 13, 2017

Published March 30, 2017

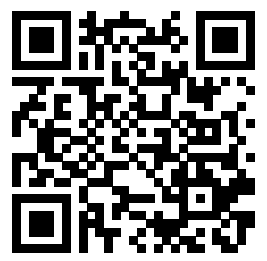

\begin{abstract}
Purpose: Caffeic acid is one of anti-oxidant phenolic acids and is abundant in plants and algae. Various reports have shown that caffeic acid inhibits ultraviolet (UV)-induced matrix metalloproteinase 1 upregulation and skin carcinogenesis, however, the photoprotective effects on human follicle dermal papilla cells (HFDPCs) have not been elucidated yet. Methods: We investigated if caffeic acid inhibits UVinduced cellular damages in HFDPCs by conducting cell viability, UV protection, intracellular reactive oxygen species (ROS), and cellular senescence detection assays. Results: We found that caffeic acid had a low cytotoxicity and significantly inhibited UVB-induced cytotoxicity on HFDPCs. In addition, treatment with caffeic acid decreased UVB-mediated intracellular ROS production in a dose-dependent manner. Furthermore, UVB-induced cellular senescence, which was detected by a senescence-associated $\beta$-galactosidase (SA- $\beta$-galactosidase) assay, markedly reduced in caffeic acid treatment before UVB irradiation on HFDPCs. Conclusion: Our data indicated that caffeic acid has protective effects against UVB-induced cellular damages on HFDPCs.
\end{abstract}

Keywords: Caffeic acid, Human follicle dermal papilla cell, Ultraviolet, Protection, Senescence

\section{Introduction}

인간 피부는 발달과정에 있어 상피-간엽 상호 활동(epithelialmesenchymal interactions)을 연구하는데 있어 상당히 다루기 쉬 운 조직이다(Driskell et al., 2011; Müller-Röver et al., 2001). 진 피 모유두 세포(dermal papilla cells)는 이러한 피부 내 간엽세포을 구성하는 한 집단에 구성되어 있으며, 기본적으로 다분화능 줄기세 포(multi-potent stem cells) 저장소로 판단될 뿐만 아니라, 모낭의 발달 및 성장 조절에 매우 필수적인 역할을 수행하는 것으로 알려 져 있다(Driskell et al., 2011). 모유두 세포의 전구체는 모낭 형성 초기에 간엽세포 응집 또는 응축된 형태로 배아 피부 진피 안에 구 성되어 있다(Driskell et al., 2011). 이러한 초기 간엽조직 형태 안에 서 모낭 발달에 대한 시작 신호가 발생되며, 이후 간엽조직과 그 조 직을 둘러싸고 있는 상피조직 상호작용을 통해 조직적으로 모낭 형 성의 이후 단계를 진행시킨다(Driskell et al., 2011).

비록 자외선(UV)은 인간 피부에 vitamin $\mathrm{D}$, melanocortins, adrenocorticotropic hormone, corticotropin-releasing hormone 등의 합성을 유도하여 생물학적으로 유익한 효능을 발휘하나, 지 나친 자외선은 오히려 피부에 해로운 영향을 미치는 주요 요인으로 여겨진다(Lu et al., 2009). 이러한 자외선은 표피의 기저층에 존재 하는 각질형성세포의 성장을 억제하고, 염증성 반응 및 산화적 스 트레스(ROS)를 유발하여, 각질형성세포의 세포사멸(apoptosis), 피 부 노화, 발암기전을 촉진하는 것으로 보고된다(Lu et al., 2009). 이 렇듯 인간 피부에 대한 자외선 영향에 관한 논문들은 대부분이 표피층 과 진피층에 집중되어 많은 과학적인 결과를 보여주고 있으나, 모낭과 같은 피부 부속기관들의 자외선 영향에 관한 연구는 많은 부분이 아직 진행중에 있다(Kim et al., 2016; Lu et al., 2009). 지금까지의 자외선 이 모낭에 미치는 영향에 관한 연구논문들에 의하면, 자외선은 피 부외조직인 모간(hair shaft)에 손상을 미칠 뿐만 아니라(Nogueira et al., 2004), 모간 생성체인 모상 각질형성세포, 진피 모유두에 영향을 미쳐 세포사멸을 통한 모발의 성장, 주기에 변화를 유발시킬 수 있음 이 밝혀졌다(Lu et al., 2009). 


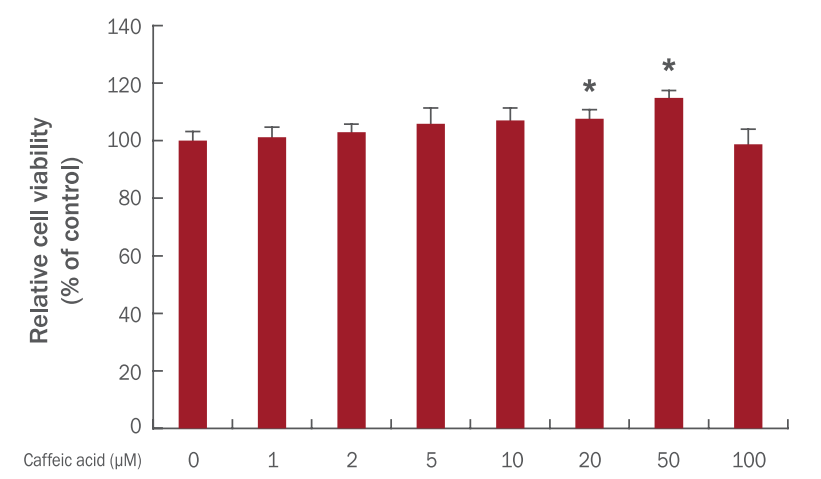

Figure 1. Analysis of cell viability in caffeic acid-treated HFDPCs.

Human follicle dermal papilla cells (HFDPCs) were treated with the indicated doses of caffeic acid for $24 \mathrm{~h}$. And then cell viability was detected by using a water soluble tetrazolium-1 (WST-1) assay. The results are presented as mean \pm standard deviation (M \pm S.D.) of three independent experiments. ${ }^{*} p<0.05$ compared with control sample (untreated group of caffeic acid).

카페인산(caffeic acid)은 다양한 식물 및 조류에서 많이 발견되는 페놀산(phenolic acid) 중 하나로 $\mathrm{a}, \beta$-불포화 카르복실산기와 카테 콜 그룹을 가지고 있는 천연물질이다(Kang et al., 2006). 현재까지 의 연구를 통해, 카페인산은 항산화(Vieira et al., 1998), xanthine oxidase 및 glutathione $\mathrm{S}$-transferase 효소활성 억제(Chan et al., 1995; Ploemen et al., 1993), 항암(Tanaka et al., 1993), 항염 (Fernández et al., 1998), 항바이러스(Kashiwada et al., 1995) 등 다 양한 생물학적 효능을 보유하는 것으로 나타났다. 특히 피부에 있어 서, 카페인산은 각질형성세포의 분화를 촉진하며(Kim et al., 2014), 자외선에 의한 염증(Balupillai et al., 2015), 발암기전(Yang et al., 2014) 및 각질형성세포 내 matrix metalloproteinase 1 발현 (Pluemsamran et al., 2012) 등을 억제하는 것으로 보고되고 있으나, 두피 및 두피 구성세포에 관한 효능에 있어서는 아직 연구되지 않았다. 이에 본 연구에서는 카페인산이 자외선에 의한 진피 모유두 세포 손상 에 미치는 영향을 규명하고자 한다.

\section{Methods}

\section{Cell culture and reagents}

인간 진피 모유두 세포(HFDPCs)는 Innoprot (Spain)에서 구 입하여, $37^{\circ} \mathrm{C}$ 와 $5 \% \mathrm{CO}_{2}$ 조건하에 $10 \%$ fetal bovine serum (FBS; $\mathrm{Gibco}^{\mathrm{TM}}$, Thermo Fisher Scientific, USA)와 1\% penicillinstreptomycin (Gibco ${ }^{\mathrm{TM}}$, Thermo Fisher Scientific)이 함유된 Dulbecco's Modified Eagle Medium (Gibco ${ }^{\mathrm{TM}}$, Thermo Fisher Scientific)을 이용하여 배양하였다. 카페인산은 Sigma-Aldrich



Figure 2. Caffeic acid protects HFDPCs against the UVBmediated reduction in viability.

HFDPCs were pretreated with the indicated doses of caffeic acid for the indicated time followed by ultraviolet B (UVB) irradiation. And then cell viability was detected by using a WST-1 assay. The results are presented as $\mathrm{M} \pm$ S.D. of three independent experiments. ${ }^{*} p<0.05$ compared with control sample (untreated group of caffeic acid).

(USA)에서 구입하였으며, dimethyl sulfoxide (DMSO; SigmaAldrich)에 녹여 사용하였다.

\section{Analysis of cell viability}

세포생존율(cell viability)은 water soluble tetrazolium-1 (WST-1) assay solution 제품(EZ-Cytox Cell Viability Assay Kit; Itsbio, Korea)을 사용하여 측정하였다. 진피 모유두 세포를 96well plate에 $4 \times 10^{3} \mathrm{cells} / \mathrm{well}$ 농도로 접종한 후, $70-80 \%$ 의 밀도가 되 도록 배양시켰으며, 농도 1-100 $\mu \mathrm{M}$ 의 카페인산을 $24 \mathrm{~h}$ 동안 처리하 였다. 이후 WST-1 assay solution을 처리하여 추가적으로 $30 \mathrm{~min}$ 배양한 후, iMark ${ }^{\mathrm{TM}}$ microplate absorbance reader (Bio-Rad Laboratories, USA)를 이용하여 $490 \mathrm{~nm}$ 파장대에서 optical density 값을 측정하였다. 각 실험은 최소 3 번 반복하였으며, $p$-value는 Student's t-test를 이용하여 분석하였다. $p<0.05$ 는 통계 학적으로 유의한 차이를 나타낸다.

\section{UVB protection assay}

진피 모유두 세포를 $60 \mathrm{~mm}$ dish에 $2 \times 10^{6}$ cells/well의 농도로 접종한 후, $10,20,50,100 \mu \mathrm{M}$ 농도의 카페인산을 $3,6,12 \mathrm{~h}$ 동안 처리하였다. 이후 phosphate buffered saline (PBS)를 이용하여 배양액을 수세한 후, 배양접시의 뚜껑이 없는 상태에서 $15 \mathrm{~mJ} / \mathrm{cm}^{2}$ $\mathrm{UVB}$ 를 조사하였다. 이후 새로운 배양액으로 바꾸어 $24 \mathrm{~h}$ 배양시 킨 후, WST-1 assay를 이용하여 세포생존율을 측정하였다.

\section{Analysis of intracellular levels of ROS}

진피 모유두 세포를 $60 \mathrm{~mm}$ dish에 $2 \times 10^{6}$ cells/well의 농 


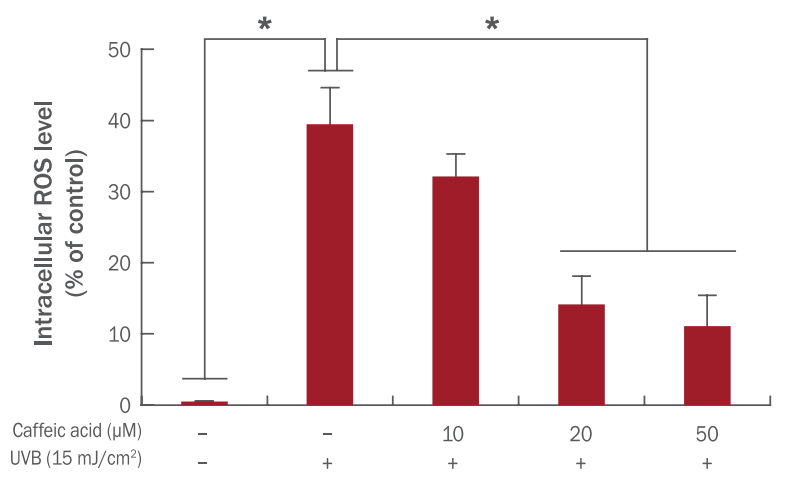

Figure 3. Caffeic acid downregulates the level of intracellular ROS in HFDPCs.

HFDPCs were treated with the indicated doses of caffeic acid for $12 \mathrm{~h}$ followed by irradiation to UVB. And then intracellular reactive oxygen species (ROS) levels were measured by using a flow cytometric analysis. The results are presented as $\mathrm{M} \pm$ S.D. of three independent experiments. ${ }^{*} p<0.05$ compared with control sample (untreated group of caffeic acid and UVB).

도로 접종한 후, 카페인산을 $12 \mathrm{~h}$ 동안 처리하였다. 이후 15 $\mathrm{mJ} / \mathrm{cm}^{2} \mathrm{UVB}$ 를 조사하였다. Intracellular ROS level은 2'7' -dichlorofluorescein diacetate (DCFDA; Sigma-Aldrich)를 이 용하여 측정하였다. 먼저, 처리된 세포를 $10 \mu \mathrm{M} \mathrm{DCFDA}$ 용액에 재 부유시킨 후, $1 \mathrm{~h}$ 동안 어두운 곳에서 실온 배양시켜, 형광이 생성 되도록 유도하였다. 형광값은 BD FACSCalibur ${ }^{\mathrm{TM}}$ flow cytometer (BD Biosciences, USA)를 통해 측정하였으며, $\mathrm{DCF}$ fluorescence intensity 평균값은 FL1-H channel를 이용하여 10,000개 세포를 측정하여 나온 결과를 바탕으로 백분율로 계산하였다.

\section{Analysis of cellular senescence}

카페인산를 전처리 한 진피 모유두 세포에 UVB에 노출시 킨 후, $48 \mathrm{~h}$ 배양시켰다. 이후 세포를 PBS로 수세한 후, $2 \%$ formaldehyde/0.2\% glutaraldehyde (Sigma-Aldrich)를 이용하여 고정하였다. 세포노화(cellular senescence) 정도를 측정하기 위해, 고정화된 세포를 $\mathrm{PBS}$ 로 수세한 후, $\mathrm{SA}-\beta$-galactosidase staining solution (BioVision, $\mathrm{USA}$ )을 $37^{\circ} \mathrm{C}$ 에서 $15 \mathrm{~min}$ 동안 처리하였 다. 파란색으로 염색된 세포를 bright-field microscope (CKX41; Olympus, Japan)를 이용하여 관찰하였으며, 각기 다른 세 부분에 존재하는 세포들을 계산하여 염색된 세포의 백분율을 구하였다.

\section{Results and Discussion}

\section{1. 인간 진피 모유두 세포에서 카페인산의 세포독성 확인}

먼저, 카페인산이 인간 진피 모유두 세포에 미치는 영향을 분석

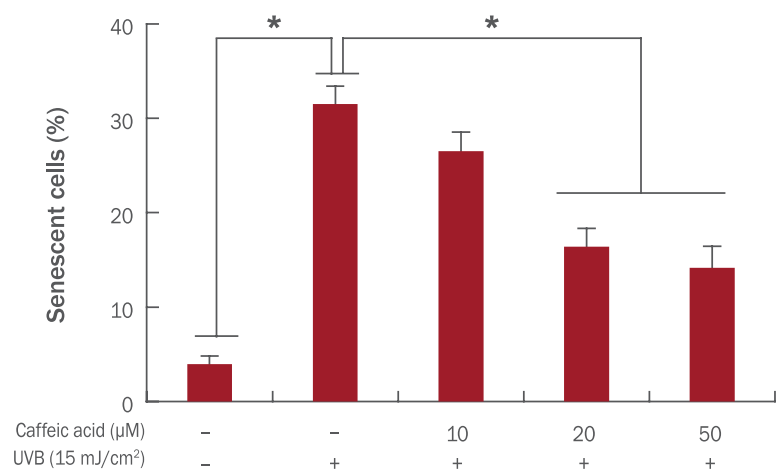

Figure 4. Caffeic acid inhibits cellular senescence induced by UVB irradiation in HFDPCs.

HFDPCs were treated with the indicated doses of caffeic acid for $12 \mathrm{~h}$ followed by irradiation to UVB. And then cellular senescence level was measured by using a senescenceassociated $\beta$-galactosidase assay. The results are presented as $\mathrm{M} \pm$ S.D. of three independent experiments. ${ }^{*} p<0.05$ compared with control sample (untreated group of caffeic acid and UVB).

하고자, WST-1 assay를 이용하여 0-100 $\mu \mathrm{M}$ 농도대의 카페인산 을 $24 \mathrm{~h}$ 동안 처리하여 모유두 세포의 세포생존율을 측정하였다. 그 결과 $100 \mu \mathrm{M}$ 이하의 카페인산 농도대에서는 세포생존율의 감 소가 나타나지 않았으며, 특히 $20 \mu \mathrm{M}$ 와 $50 \mu \mathrm{M}$ 농도에서는 대조군 대비 통계학적으로 유의하게 세포생존율을 증가시켰다(Figure 1). 상기 결과를 바탕으로 이후 실험은 $100 \mu \mathrm{M}$ 이하의 카페인산 농도 대를 사용하여 진행하였다.

\section{2. 인간 진피 모유두 세포에서 카페인산의 UVB에 의한 세포독 성 보호 효과}

카페인산은 인간 각질세포주인 $\mathrm{HaCaT}$ 세포에서 UVA에 의 한 세포독성을 현저하게 억제한다고 보고되었다(Pluemsamran et al., 2012). 또한, 카페인산은 마우스 실험을 통해 UVB에 의한 carcinogenesis 억제 효능을 보였다(Balupillai et al., 2015). 이를 바탕으로, 본 연구에서는 추가적으로 인간 진피 모유두 세포에서 UVB에 의한 세포 손상 유발에 있어 카페인산의 효능을 분석하고 자 하였다. 먼저, 모유두 세포에 UVB를 조사하기 전에 $3 \mathrm{~h}$ 동안 카 페인산을 전처리한 결과, $50 \mu \mathrm{M}$ 이하 농도대에서 농도 의존적으로 UVB에 의한 세포생존율 감소를 억제하는 효과가 나타났다(Figure 2). 또한, 카페인산을 UVB 조사 전에 $6 \mathrm{~h}$ 전처리한 결과, 동일 농 도대의 $3 \mathrm{~h}$ 전처리 실험군에서 나타나는 결과값보다 증가됨을 보 였다. 뿐만 아니라, 카페인산을 UVB 조사 전에 $12 \mathrm{~h}$ 전처리한 결과, 앞선 $3 \mathrm{~h}$ 및 $6 \mathrm{~h}$ 전처리의 실험군 값에 비해 자외선에 의한 세포독 성 보호 효능이 더 높아짐을 보였다. 따라서, 본 결과를 통해 카페인 산은 UVB 의존적 모유두 세포독성에 보호 효능이 있음을 나타낸다. 


\section{3. 인간 진피 모유두 세포에서 카페인산의 UVB에 의한 산화적 스트레스 보호 효과}

$\mathrm{UVB}$ 는 여러 세포 내에서 ROS 생산에 관여하는 주요한 유도 자 중 하나이다. 따라서, 본 연구에서는 카페인산의 UVB에 의한 세포독성 보호 효능이 ROS 생성 억제와 관련 있는지 파악하고자 하였다. 먼저 카페인산을 UVB 조사 전에 $12 \mathrm{~h}$ 전처리 해주었다. UVB 조사 이후 $24 \mathrm{~h}$ 배양시키고, 세포 내 존재하는 ROS level를 $\mathrm{DCFDA}$ fluorescent dye를 이용하여 분석하였다. 그 결과, UVB 조 사는 모유두 세포 내 ROS level을 $39.48 \pm 5.14 \%$ 증가시켰으나, 10, $20,50 \mu \mathrm{M}$ 카페인산을 전처리한 실험군에서는 UVB 조사 이후 세 포 내 ROS level이 $32.14 \pm 3.17 \%, 14.14 \pm 3.96 \%, 11.10 \pm 4.31 \%$ 로 현저하게 감소하였다(Figure 3). 이러한 결과를 토대로, 진피 모유 두 세포에 있어 카페인산에 의한 UVB 의존적 세포 손상 보호 효능 은 ROS 생성억제 효능과 연관되어 있음을 나타낸다.

\section{4. 인간 진피 모유두 세포에서 카페인산의 UVB에 의한 세포노 화 보호 효과}

높은 수준의 ROS는 세포노화의 주요한 원인 중 하나로 알려져 있다. 기존 보고에서, 초기 탈모에서 나타나는 모유두 세포의 조기 노화(premature senescence)는 세포 내 SA- $\beta$-galactosidase의 발 현 변화와 연관되어 있으며, 이러한 모유두 세포의 조기노화에는 산화적 스트레스가 관여되어 있을 것으로 보고 있다. 따라서, 본 논 문에서는 추가적으로 자외선에 의한 모유두 세포의 세포노화 유 발에 있어 카페인산의 효능을 분석하고자 하였다. 모유두 세포를 앞선 실험(Figure 3)과 동일하게 카페인산을 전처리한 후 UVB를 조사하여 나타나는 세포노화를 SA- $\beta$-galactosidase detection assay를 이용하여 분석하였다. UVB 조사는 대조군 대비 $31.50 \pm$ $1.90 \%$ 세포노화가 증가됨을 확인하였다(Figure 4). 흥미롭게도, 자 외선을 조사하기 전에 카페인산을 $10,20,50 \mu \mathrm{M}$ 농도로 전처리 한 실험군에서는 세포노화의 비율이 각각 $26.50 \pm 2.03 \%, 16.41 \pm$ $1.93 \%, 13.94 \pm 2.31 \%$ 로 나타났다. 이를 통해, 카페인산은 UVB에 의한 모유두 세포의 세포노화를 현저하게 억제하는 효능이 있음을 밝혔다.

\section{Conclusion}

본 논문에서는, UVB 의존적 모유두 세포 손상에 대한 카페인산 의 보호 효능을 생화학적 분석법을 통해 증명하였다. 특히, 카페인 산의 전처리는 UVB 조사에 의한 세포독성, 세포 내 ROS 생산, 세 포노화를 현저하게 억제하였다. 비록 이러한 카페인산의 보호 효능 관련 특이적 세포신호전달체계를 증명하지 못하였으나, 본 연구논 문은 탈모를 예방 및 억제할 수 있는 가능성 높은 물질로서 카페인 산 발견에 그 중요성이 있다.
최근의 연구논문들은 탈모에 있어 산화적 스트레스에 대한 영향 을 제시하고 있으며, 이는 산화적 스트레스의 억제는 탈모 및 백모 화를 조절하는데 중요한 신규 전략으로 제시될 수 있음을 나타낸다 (Trüeb, 2009). 과거 사례연구에 따르면, 탈모가 없는 정상인과 비 교하여 원형 탈모(alopecia areata)를 가진 환자에서 산화적 스트 레스가 상대적으로 높다는 것을 증명하였다(Bakry et al., 2014). 게다가, 마우스를 이용한 실험을 통해 염색약에 의해 유도되는 탈 모는 대부분 hydrogen peroxide에 의해 유도되는 산화적 스트레스 가 원인이라고 보고되었다(Seo et al., 2012).

산화적 스트레스는 모낭 성장 저해제 및 남성형 탈모(androgenic alopecia)의 주요한 원인으로 알려진 transforming growth factor $\beta$ 의 생산을 촉진시킨다(Lee \& Hwang, 2009; Shin et al., 2013). 이전의 논문에서 카페인산은 인간 각질세포에 있어 UVA에 대한 광 보호 효과(photoprotective effects)를 증명하였으며(Pluemsamran et al., 2012), 여러 임상 및 이론 논문들은 자외선은 산화적 스트 레스, 휴지기 탈모(telogen effluvium), 모낭-미세염증(follicular micro-inflammation) 등의 유도를 통해 모발의 성장에 부정적인 영향을 나타냄을 밝혔다(Camacho et al., 1996; Johnsson et al., 1987; Trüeb, 2003).

따라서, 산화적 스트레스를 억제하는 것은 스트레스 및 안드로겐 의존적 탈모를 극복하는데 중요한 전략으로 사료될 수 있다. 본 연 구에서는 카페인산은 모유두 세포에서 산화적 스트레스에 의한 세 포 손상을 억제할 뿐만 아니라 모유두 세포에 세포독성을 거의 유발 하지 않음을 확인하였다. 따라서, 추후 임상학적인 연구를 통해 카 페인산의 두피 도포에 따른 영향을 분석함으로써, 카페인산을 탈모 예방 및 탈모억제의 기능성 물질로 개발하는데 기초 자료로서 활용 될 수 있을 것으로 사료된다.

\section{Acknowledgements}

이 논문은 2016년도 건국대학교 KU학술연구비 지원에 의한 논문임.

\section{References}

Bakry OA, Elshazly RM, Shoeib MA, Gooda A. Oxidative stress in alopecia areata: a case-control study. American Journal of Clinical Dermatology, 15: 57-64, 2014.

Balupillai A, Prasad RN, Ramasamy K, Muthusamy G, Shanmugham M, Govindasamy K, Gunaseelan S. Caffeic acid inhibits UVB-induced inflammation and photocarcinogenesis through activation of peroxisome proliferator-activated receptor-y in mouse skin. Photochemistry and Photobiology, 91: 1458-1468, 2015. Camacho F, Moreno JC, García-Hernández MJ. Telogen 
alopecia from UV rays. Archives of Dermatology, 132: 1398-1399, 1996.

Chan WS, Wen PC, Chiang HC. Structure-activity relationship of caffeic acid analogues on xanthine oxidase inhibition. Anticancer Research, 15: 703-707, 1995.

Driskell RR, Clavel C, Rendl M, Watt FM. Hair follicle dermal papilla cells at a glance. Journal of Cell Science, 124: 1179-1182, 2011.

Fernández MA, Sáenz MT, García MD. Anti-inflammatory activity in rats and mice of phenolic acids isolated from Scrophularia frutescens. Journal of Pharmacy and Pharmacology, 50: 1183-1186, 1998.

Johnsson A, Kjeldstad B, Melø TB. Fluorescence from pilosebaceous follicles. Archives of Dermatological Research, 279: 190-193, 1987.

Kang KA, Lee KH, Zhang R, Piao M, Chae S, Kim KN, Jeon YJ, Park DB, You HJ, Kim JS, et al. Caffeic acid protects hydrogen peroxide induced cell damage in WI-38 human lung fibroblast cells. Biological and Pharmaceutical Bulletin, 29: 1820-1824, 2006.

Kashiwada Y, Nishizawa M, Yamagishi T, Tanaka T, Nonaka G, Cosentino LM, Snider JV, Lee K. Anti-AIDS agents, 18. sodium and potassium salts of caffeic acid tetramers from Arnebia euchroma as anti-HIV agents. Journal of Natural Products, 58: 392-400, 1995.

Kim B, Kim JE, Kim HS. Caffeic acid induces keratinocyte differentiation by activation of PPAR- $\alpha$. Journal of Pharmacy and Pharmacology, 66: 84-92, 2014.

Kim KS, Han SH, An IS, Ahn KJ. Protective effects of ellagic acid against UVA-induced oxidative stress in human dermal papilla. Asian Journal of Beauty and Cosmetology, 14: 191-200, 2016.

Lee HS, Hwang SY. Effects of DCS ${ }^{\circledR}$ hair tonic on hair growth promotion in an alopecia model of C57BL/6 mice. Asian Journal of Beauty and Cosmetology, 7: 131-141, 2009.

Lu Z, Fischer TW, Hasse S, Sugawara K, Kamenisch Y, Krengel S, Funk W, Berneburg M, Paus R. Profiling the response of human hair follicles to ultraviolet radiation. Journal of Investigative Dermatology, 129: 1790-1804, 2009.

Müller-Röver S, Handjiski B, van der Veen C, Eichmüller S, Foitzik K, McKay IA, Stenn KS, Paus R. A comprehensive guide for the accurate classification of murine hair follicles in distinct hair cycle stages. Journal of Investigative Dermatology, 117: 3-15, 2001.
Nogueira AC, Nakano AK, Joekes I. Impairment of hair mechanical properties by sun exposure and bleaching treatments. Journal of Cosmetic Science, 55: 533-537, 2004.

Ploemen JH, van Ommen B, de Haan A, Schefferlie JG, van Bladeren PJ. In vitro and in vivo reversible and irreversible inhibition of rat glutathione S-transferase isoenzymes by caffeic acid and its 2-S-glutathionyl conjugate. Food and Chemical Toxicology, 31: 475-482, 1993.

Pluemsamran T, Onkoksoong T, Panich U. Caffeic acid and ferulic acid inhibit UVA-induced matrix metalloproteinase-1 through regulation of antioxidant defense system in keratinocyte HaCaT cells. Photochemistry and Photobiology, 88: 961-968, 2012.

Seo JA, Bae IH, Jang WH, Kim JH, Bak SY, Han SH, Park YH, Lim KM. Hydrogen peroxide and monoethanolamine are the key causative ingredients for hair dye-induced dermatitis and hair loss. Journal of Dermatological Science, 66: 12-19, 2012.

Shin H, Yoo HG, Inui S, Itami S, Kim IG, Cho AR, Lee DH, Park WS, Kwon $\mathrm{O}$, Cho $\mathrm{KH}$, et al. Induction of transforming growth factor-beta 1 by androgen is mediated by reactive oxygen species in hair follicle dermal papilla cells. $B M B$ Reports, 46: 460-464, 2013.

Tanaka T, Kojima T, Kawamori T, Wang A, Suzui M, Okamoto $\mathrm{K}$, Mori $\mathrm{H}$. Inhibition of 4-nitroquinoline-1-oxide-induced rat tongue carcinogenesis by the naturally occurring plant phenolics caffeic, ellagic, chlorogenic and ferulic acids. Carcinogenesis, 14: 1321-1325, 1993.

Trüeb RM. Is androgenetic alopecia a photoaggravated dermatosis? Dermatology, 207: 343-348, 2003.

Trüeb RM. Oxidative stress in ageing of hair. International Journal of Trichology, 1: 6-14, 2009.

Vieira O, Laranjinha J, Madeira V, Almeida L. Cholesteryl ester hydroperoxide formation in myoglobin-catalyzed low density lipoprotein oxidation: concerted antioxidant activity of caffeic and $p$-coumaric acids with ascorbate. Biochemical Pharmacology, 55: 333-340, 1998.

Yang G, Fu Y, Malakhova M, Kurinov I, Zhu F, Yao K, Li H, Chen H, Li W, Lim DY, et al. Caffeic acid directly targets ERK1/2 to attenuate solar UV-induced skin carcinogenesis. Cancer Prevention Research, 7: 1056-1066, 2014. 


\section{국문초록}

\section{카페인산 처리를 통한 자외선B에 의해 유도된 세포 손상의 보호 효과 분석}

안규중

건국대학교 의학전문대학원 피부과학교실, 서울, 한국

목적: 카페인산은 식물 및 조류에 많이 발견되는 항산화 페놀산 중 하나이다. 여러 논문들을 통해 카페인산은 자외선에 의한 matrix metalloproteinase 1 발현 및 피부 발암기전을 억제한다고 보고되고 있지만, 인간 진피 모유두 세포에 대한 광보호 효과에 대해서 는 연구되지 않고 있다. 방법: 카페인산이 자외선에 의한 진피 모유두 세포 손상에 어떠한 영향을 미치는지에 대해서 cell viability, ultraviolet (UV), intracellular reactive oxygen species (ROS) 및 cellular senescence detection assays를 통하여 분석하였다. 결과: 카페인산은 진피 모유두 세포에 세포독성을 유발하지 않았으며, 자외선B에 의한 세포독성을 현저하게 감소시켰다. 또한, 카페 인산의 처리는 자외선B에 의해 유도되는 세포 내 ROS 생성을 농도 의존적으로 감소시켰다. 뿐만 아니라, 진피 모유두 세포에 자외선B 를 처리하기 전 카페인산의 전처리는 자외선B에 의해 유도되는 세포노화를 현저하게 억제하였다. 결론: 본 연구결과를 통해 카페인산 은 진피 모유두 세포에 있어, 자외선B에 의한 세포 손상을 보호하는 효능을 가짐을 증명하였다.

핵심어: 카페인산, 인간 진피 모유두 세포, 자외선, 보호, 노화

이 논문은 2016년도 건국대학교 KU학술연구비 지원에 의한 논문임.

\section{참고문헌}

김경숙, 한송희, 안인숙, 안규중. UVA가 유도하는 산화적 스트레스에 Ellagic Acid가 미치는 인간 모유두 세포 보호효과. 아시안 뷰티화장품학술지, 14: 191-200, 2016.

이혜숙, 황석연. C57BL/6마우스 모델에서 DCS-HT® 발모제의 모발성장 촉진 효과. 아시안뷰티화장품학술지, 7: 131-141, 2009. 


\section{中文摘要}

\section{咖啡酸对紫外线B诱导细胞损伤的保护作用}

安圭重

建国大學医科专门大學院皮肤科，首尔，韩国

目的: 咖啡酸是抗氧化酚酸之一，在植物和藻类中丰富。各种报告已经表明咖啡酸抑制紫外线诱导的基质金属蛋白酶1表 达和皮肤致癌作用。然而, 对人毛囊真皮乳头细胞 (human follicle dermal papilla cells, HFDPCs) 的光保护作用尚未阐 明。方法：通过分析cell viability, ultraviolet (UV), intracellular reactive oxygen species (ROS) 以及 cellular senescence detection assays调查咖啡酸对紫外线照射损伤的人毛囊真皮乳头细胞的影响。结果: 发现咖啡酸对真皮乳头细胞没有产生 细胞毒性, 并减少了UVB诱导产生的HFDPCs细胞的毒性。此外, 用咖啡酸处理时, 以剂量依赖性方式降低UVB诱导产生 的细胞内ROS。还有在UVB照射之前, 提前用咖啡酸处理时, 明显抑制UVBi诱导的细胞衰老。结论: 通过研究证明, 咖啡 酸对于UVB诱导人毛囊真皮乳头细胞损伤具有保护作用。

关键词: 咖啡酸，人毛囊真皮乳头细胞，紫外线，保护，衰老 